\title{
STUDY OF CLINICAL SIGNIFICANCE OF PAP SMEAR IN STD CLINICS
}

\author{
M. Parvathi', P. Guru Prasad², Rashmi Naldeega ${ }^{3}$, G. Divya Lekha ${ }^{4}$ \\ ${ }^{1}$ Assistant Professor, Department of Dermatology, Venereology and Leprosy, Andhra Medical College. \\ 2 Professor, Department of Dermatology, Venereology and Leprosy, Andhra Medical College. \\ 3 Junior Resident, Department of Dermatology, Venereology and Leprosy, Andhra Medical College. \\ ${ }^{4}$ Junior Resident, Department of Pathology, Andhra Medical College.
}

\section{ABSTRACT}

AIM

The objective of this study is to analyse the association between sexually transmitted diseases and cervical cytology by doing Papanicolaou (Pap) smear in the female patients attending Sexually Transmitted Disease (STD) Clinics.

\section{MATERIALS AND METHODS}

The present study was carried out on 200 female patients attending STD clinic Outpatient Department (OPD) in King George Hospital (KGH) for a period of 2 years. For all the patients Pap smears were taken.

\section{RESULTS}

A $39 \%$ of the cases had normal cytology, 26\% had inflammatory cytology, $16 \%$ had mild dysplasia, $13.5 \%$ had moderate dysplasia, $5.5 \%$ had severe dysplasia. Higher incidence of cervical dysplasia was seen in patients with Genital Herpes and Genital warts. Higher incidence of cervical dysplasia (42.6\%) in 20 to 30 years age group women in comparsion with diminished incidence in (28.7\%) in 30 to 40 years age group. A 44.6\% in Commercial Sex workers and women with history of sexual promiscuity had cervical dysplasia and $28.7 \%$ women having normal marital life had cervical dysplasia. We found higher number of cervical dysplasia in lower income group (37.8\%) and (42.6\%) in illiterates.

\section{CONCLUSIONS}

Pap smear should be done as a routine screening procedure in all female patients attending STD Clinics to detect early cervical neoplasia, which will help to reduce morbidity and mortality due to cancer cervix in sexually active reproductive age group women.

\section{KEYWORDS}

Papanicolaou Smear, Cervical Dysplasia, Sexual Promiscuity.

HOW TO CITE THIS ARTICLE: M. Parvathi, P. Guru Prasad, Rashmi Naldeega, G. Divya Lekha. "Study of Clinical Significance of Pap Smear in STD Clinics." Journal of Evolution of Medical and Dental Sciences 2015; Vol. 4, Issue 100, December 14;

Page: 16558-16562, DOI: $10.14260 /$ jemds/2015/2465

\section{INTRODUCTION}

Carcinoma cervix worldwide accounts for $15 \%$ of all cancers diagnosed in women.[1] Cervical cancer is one of the leading cancer in women with the estimated 5.0 lakhs new cases every year, of which $80 \%$ occur in developing countries.[2] In India, it is estimated that the number of new cases are over 140,000.[3] The role of Papanicolaou (Pap) smear as a cancer screening tool for the cervix has been substantiated by several studies in the last 50 years. ${ }^{[4,5]}$ and the method has resulted in falling incidence and mortality of cervical cancer in the developed world. [6,7,8]

The present study helps:

To evaluate the efficacy of Pap smear as routine screening procedure for early detection of early dysplastic changes in the cervix.

Financial or Other, Competing Interest: None.

Submission 04-11-2015, Peer Review 05-11-2015,

Acceptance 14-11-2015, Published 14-12-2015.

Corresponding Author:

Dr. M. Parvathi,

Assistant Professor, Department of DVL,

Andhra Medical College, KGH,

Visakhapatnam.

E-mail: dvlkgh2015@gmail.com

DOI:10.14260/jemds/2015/2465
To evaluate the effect of sexually transmitted diseases on cervical cytology.

To evaluate the effect of socioeconomical factors like early marital life, parity, literacy, income status and occupational status on cervical dysplasia.

To evaluate the effect of high risk behavior like multiple sexual exposures with multiple partners on cervical intraepithelial neoplasia.

\section{AIM}

The objective of this study is to analyse the association between sexually transmitted diseases and cervical cytology by doing Pap smear in the female patients attending STD Clinics.

\section{MATERIAL AND METHODS}

The present study was carried out on 200 female patients attending STD OPD, KGH for a period of 2 years.

\section{Inclusion Criteria}

The female patients above 18 years of age who came with different complaints like vaginal discharge, genital ulcers and 
other genital lesions after obtaining informed consent were included in this study.

For all the patients routine screening procedures like VDRL, ELISA for HIV, urine for microscopy and culture, fasting blood sugar tests were done.

Smears were taken in patients with genital ulcers and vaginal discharge for $\mathrm{KOH}$, wet mount, Gram staining and dark ground examination.

For all the patient's Pap smears were taken and sent to the Department of Pathology for study of cervical cytology.

Relevant data like Past History of genital ulcers, vaginal discharge and Personal History regarding marital status, income status, educational status, parity, usage of contraceptives and sexual exposures taken in detail.

\section{Pap Smear-Procedure}

Instruments required: Sims vaginal speculum, Vulsellum, Ayre's spatula, Glass slides and cover slips, 95\% ethyl alcohol for fixation [Figure 1].

Patient was kept in lithotomy position. Speculum was introduced into the vagina to visualize the cervix under good light.

The long arm of Ayre's spatula was introduced into the cervical canal and rotation was done at $360^{\circ}$ angle to include ectocervix and squamocolumnar junction. The sample collected with Ayre's spatula was spread on a glass slide and dipped in 95\% ethyl alcohol to avoid drying of the smear. Take the fixed smear and dehydrate by successively passing through descending grades of alcohol $80 \%, 70 \%$ and 50\%. Stain with Harris' haematoxylin for 2 to 5 minutes. Rinse in tap water for 5 minutes and stain in orange $\mathrm{G}$ for 3 minutes. Then dehydrate by passing through absolute alcohol. Mount slide in mounting media.

W. H. O. Grading for Cervical Cytology: [Figure2]

Grade - I-Normal cells present.

Grade -II-Plenty of inflammatory cells present.

Grade-III-Mild-to-moderate dysplasia nuclear abnormalities with no atypical changes in cytoplasm.

Grade-IV-Severe dysplasia (or) cervical intraepethelial neoplasia, large hyperchromatic irregular nucleus with thin rim of cytoplasm surrounding nucleus.

Grade-V-Confirmed malignancy of cervix giant multinucleated cells with atypical mitotic figures.

\section{RESULTS}

Age Distribution: $46.5 \%$ of the cases were $20-30$ years of age, $24 \%$ were $30-40$ years of age, $10.5 \%$ were $40-50$ years of age, $8 \%$ were $50-60$ years of age and the remaining $11 \%$ were 18 20 years of age; $42.6 \%$ of patients in 20 to 30 years age group and $28.7 \%$ of patients in 30 to 40 years age group had cervical dysplasia.

\section{Educational Status}

A $37 \%$ of the cases were Uneducated, $29 \%$ received Primary education, $18 \%$ received Secondary education, $16 \%$ received Higher education; $37.8 \%$ of patients from lower income group and $42.6 \%$ of illiterate patients had cervical dysplasia.

Marital status: $62 \%$ of the cases were married, $22 \%$ were unmarried and $16 \%$ were commercial sex workers.

\section{Sexual Exposures}

A $63 \%$ of the cases denied history of premarital or extramarital exposure; $24 \%$ gave a history of multiple sexual exposures with single partner; $13 \%$ gave a history of multiple exposures with multiple partners.

High risk behaviour and cervical dysplasia: $44.6 \%$ of Commercial Sex workers and women with pre- and extramarital exposures had cervical dysplasia and $28.7 \%$ women having normal marital life had cervical dysplasia.

Clinical diagnosis: $19 \%$ of the cases were diagnosed as candidiasis, $18 \%$ as genital herpes [Figure 3], $13.5 \%$ as trichomoniasis, $8.5 \%$ as genital warts [Figure 4 ], $6.5 \%$ as Molluscum contagiosum, $4 \%$ as chancroid [Figure 5], 3.5\% as chancre, $2 \%$ as donovanosis [Figure 6], $1 \%$ as lymphogranuloma venereum [Figure 7], 24\% came with miscellaneous complaints.

HIV and cervical dysplasia: In our study, 33 patients were HIV seropositive and $17(51.5 \%)$ of them had mild-tomoderate cervical dysplasia.

Pap smear cytology reports: $39 \%$ of the cases had normal cytology, $26 \%$ had inflammatory cytology, $16 \%$ had mild dysplasia, $13.5 \%$ had moderate dysplasia, $5.5 \%$ had severe dysplasia.

\section{DISCUSSION}

In our study, the most common complaints in the female patients attending STD Clinic were vaginal discharge and genital ulcers. Candidiasis and Trichomoniasis were found to be common causes for the vaginal discharge. Genital Herpes was found to be the common cause for genital ulcers.

Higher incidence of cervical dysplasia was seen in patients with Genital Herpes and Genital warts. The studies done by M. H. Schiffman et al.[9] and J. M. Walboomers et al.[10] and various other studies have established the association of cervical premalignant and malignant epithelial lesions and Human Papillomaviruses (HPV).

We found predominantly inflammatory cytology in women suffering with candidiasis and trichomonas and only $17.5 \%$ had mild-to-moderate dysplastic changes.

We found higher incidence of cervical dysplasia (42.6\%) in 20 to 30 years age group women and diminished incidence in $(28.7 \%)$ in 30 to 40 years age group; whereas Kobelin et al.[11] found a prevalence of $34 \%$ incidence of cervical dysplasia in 406 consecutive patients of age 30-40 years.

We found higher incidence of cervical dysplasia in lower income group $(37.8 \%)$ and $(42.6 \%)$ in illiterates. This may be due to lack of awareness and poor local hygiene. Juneja A et al. and Laara E et al., found increased risk with low socioeconomic status is attributed to a lack of screening, failure to treat precancerous conditions and lack of knowledge about prevention of Human Papillomavirus (HPV) infection. [3,7]

Women with high risk behaviour had a strong impact on cervical dysplasia. We found higher incidence of cervical dysplasia (44.6\%) in Commercial Sex workers and women with pre- and extramarital exposures in comparison with women having normal marital life $28.7 \%$. Avidime S et al., found that women in polygamous marriage have a higher prevalence of cervical dysplasia when compared to those in monogamous union, singles and the divorced.[12] 
Early onset marital life and multiparity also precipitate early dysplastic changes in cervical cytology. The studies of Castapeda-Ipiguez et al.[13] have also pointed out parity as a great risk factor in the development of cervical dysplasia.

In our study 33 patients were HIV seropositive, out of them 17 (51.51\%) patients had shown mild-to-moderate cervical dysplasia. This suggests HIV influences higher incidence of dysplastic change in the cervix. Tanko et al., from Jos reported a prevalence of $21 \%$ in the HIV positive group and $6 \%$ in the HIV negative group.[14]

\section{CONCLUSION}

Pap smear is a simple and effective screening procedure to detect early neoplastic changes in cervical cytology in reproductive age group women. Women suffering with STD and HIV have higher risk of developing cervical intraepithelial neoplasia than normal woman. Women with high risk behavior who have unprotected with multiple partners are 10 times more vulnerable to cervical neoplasia than women who are leading normal marital life. Annual screening of all HIV and STD patients is essential for followup to detect early neoplastic changes in the cervix.

Papsmear should be done as a routine screening procedure in all female patients attending STD Clinics to detect early cervical neoplasia, which will help to reduce morbidity and mortality due to cancer cervix in sexually active reproductive age group women.

\section{REFERENCES}

1. Boyle P, Ferlay J. Cancer incidence and mortality in Europe, 2004. Ann Oncol. 2005;16:481-8.

2. Tristen C, Bergstrom S. Cancer in developing countries. A threat to reproductive health Lakartidningen. 1996;93:3374-6.

3. Juneja A, Sehgal A, Sharma S, et al. Cervical cancer screening in India: Strategies revisited. Indian J Med Sci 2007;61:34-47.

4. Miller AB, Chamberlain J, Day NE, Hakama M, Prorok PC. Report on a workshop of the UICC project on Evaluation of Screening for Cancer. Int J Cancer. 1990;46:761-9.

5. Walton RJ. Editorial: The task force on cervical cancer screening programs. Can Med Assoc J 1976;114:981.

6. Hakama M, Rasanen-Virtanen U. Effect of a mass screening program on the risk of cervical cancer. Am J Epidemiol. 1976;103:512-7.

7. Laara E, Day NE, Hakama M. Trends in mortality from cervical cancer in the Nordic countries: Association with organized screening programs. Lancet. 1987;1:1247-9.

8. Anderson GH, Boyes DA, Benedet JL, Le Riche JC, Matisic JP, Suen KC, et al. Organization and results of the cervical cytology screening program in British Columbia. 195585. Br Med J (Clin Res Ed) 1988;296:975-8.

9. Schiffman MH, Bauer HM, Hoover RN, et al. "Epidemiologic evidence showing that human papillomavirus infection causes most cervical intraepithelial neoplasia." Journal of the National Cancer Institute, vol. 85, no. 12, pp. 958-964, 1993.
10. Walboomers JM, Jacobs MV, Manos MM, et al. "Human papillomavirus is a necessary cause of invasive cervical cancer worldwide." Journal of Pathology, vol. 189, no. 1, pp. 12-19, 1999.

11. Kobelin MH, Kobelin CG, Burke L, Lavin P, Niloff JM, Kim YB. Incidence and predictors of cervical dysplasia in patients with minimally abnormal Papanicolaou smears. Obstet Gynecol 1998;92:356-9.

12. Avidime S, Ahmed SA, Oguntayo A, et al. Pattern of cervical dysplasia among women of reproductive age in Zaria, Northern Nigeria. J Med Trop 2014;16:52-5.

13. Castapeda-Ipiguez MS, Toledo-Cisnernos R, AguileraDeigadillo M. Risk factors for cervicovaginal uterine cancer in women in Zecalecos. Salud Publica Mex. 1998;40:330-8.

14. Tanko NM, Echejo GO, Manasseh AN, Mandong BM, Banwat EB, Daru PH. Cervical dysplasia in HIV Seropositive Women in Nigeria Highland Medical Research J 2006;4(2):21-26.

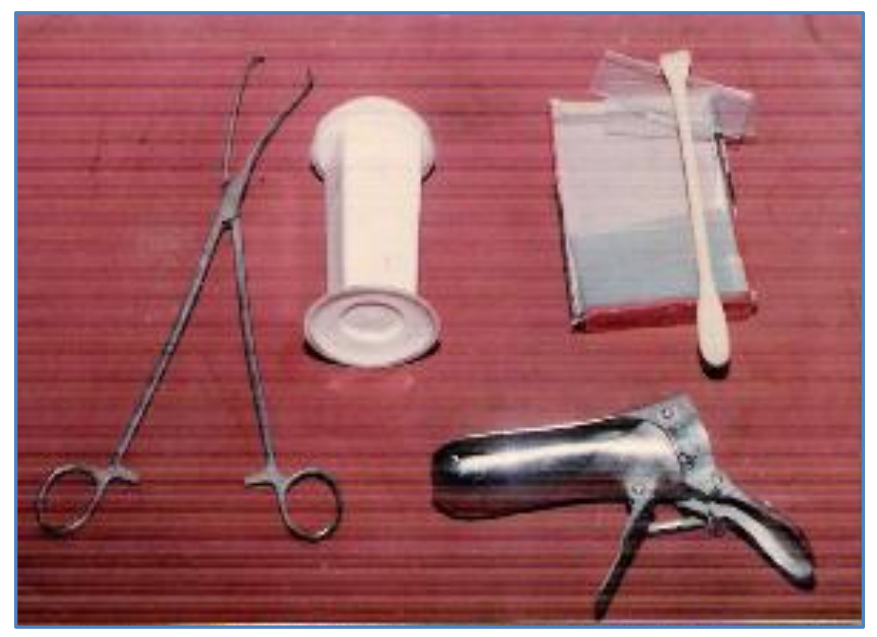

Fig.1: Instruments required for Pap smear

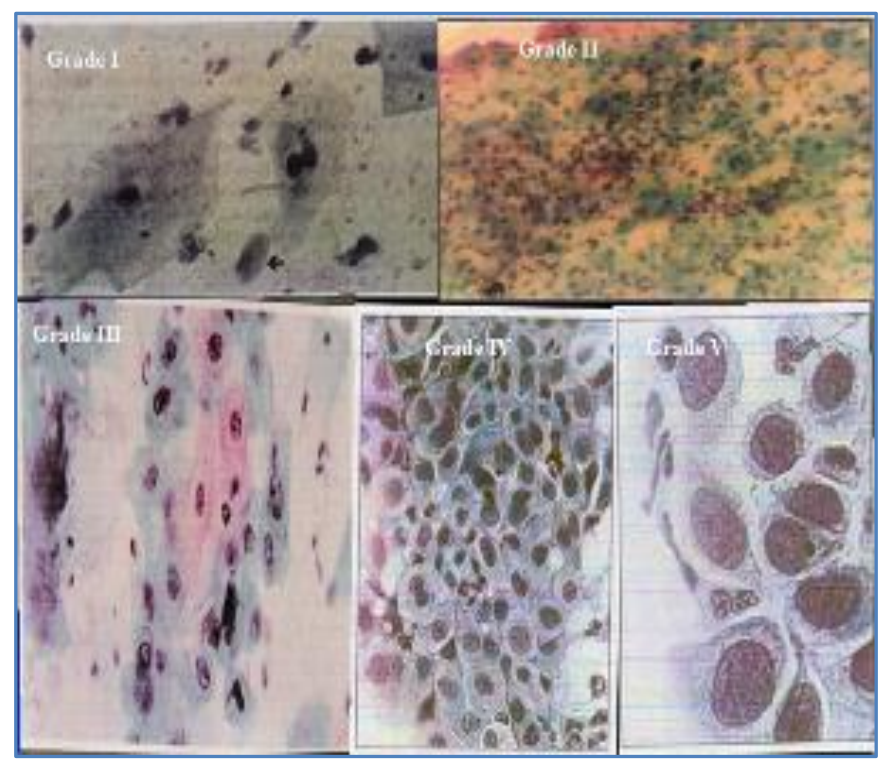

Fig.2: W.H.O. Grading for Cervical Cytology 


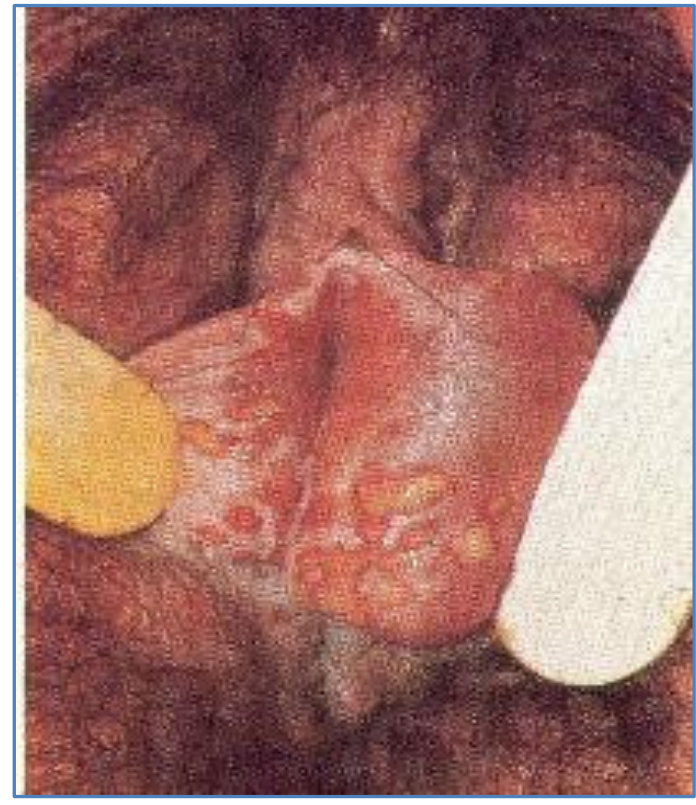

Fig.3: Herpetic Ulcers

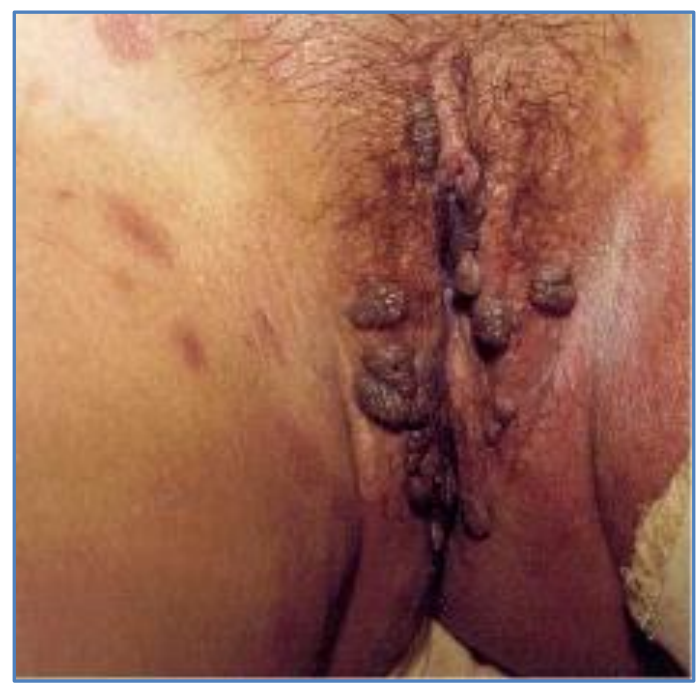

Figure 4: Genital Warts

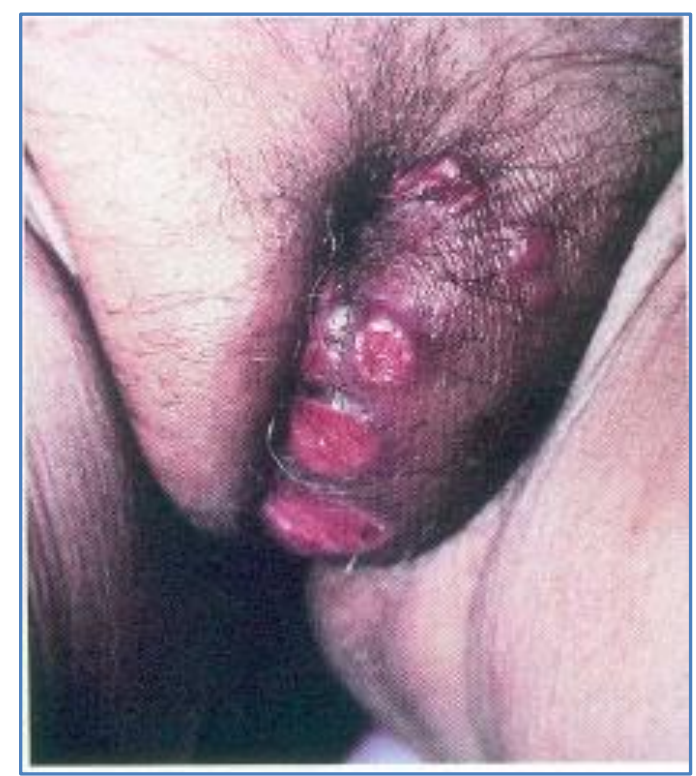

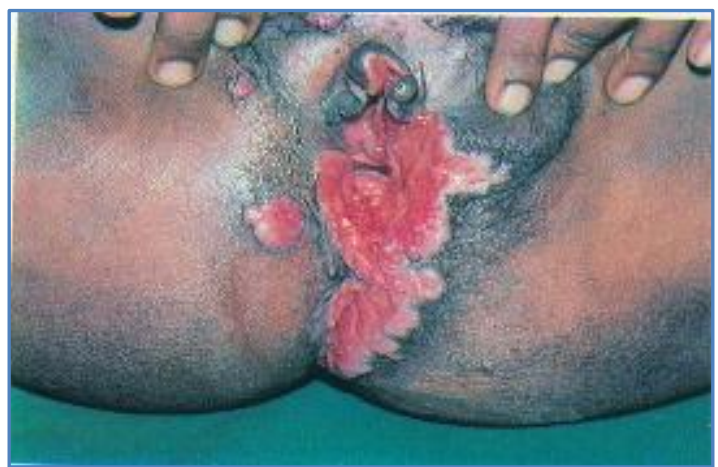

Fig. 6: Donovanosis

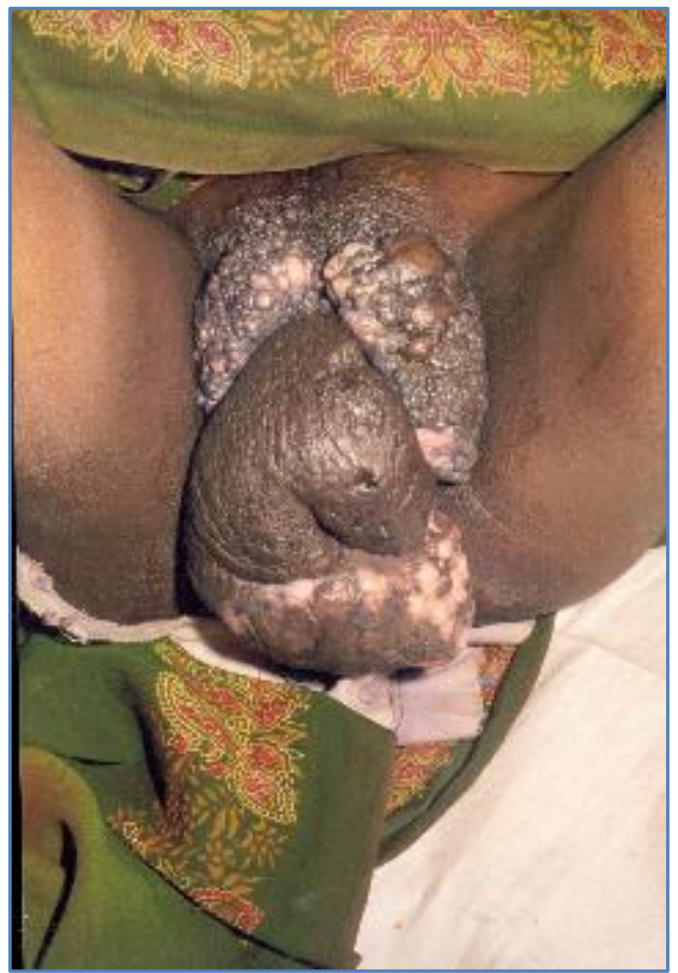

Fig. 7: Lymphogranuloma Venereum

\begin{tabular}{|c|c|c|}
\hline $\begin{array}{c}\text { Marital } \\
\text { Status }\end{array}$ & $\begin{array}{c}\text { No. of } \\
\text { Patients }\end{array}$ & $\begin{array}{c}\text { Percentage } \\
\text { (\%) }\end{array}$ \\
\hline Married & 124 & 62 \\
\hline Unmarried & 44 & 22 \\
\hline $\begin{array}{c}\text { Commercial } \\
\text { Sex workers }\end{array}$ & 32 & 16 \\
\hline Total & $\mathbf{2 0 0}$ & $\mathbf{1 0 0}$ \\
\hline \multicolumn{3}{|c|}{ Table 1: Marital Status } \\
\hline
\end{tabular}

\begin{tabular}{|c|c|c|}
\hline $\begin{array}{c}\text { Age } \\
\text { Distribution }\end{array}$ & $\begin{array}{c}\text { No. of } \\
\text { Patients }\end{array}$ & $\begin{array}{c}\text { Percentage } \\
\text { (\%) }\end{array}$ \\
\hline 10-20 Years & 22 & 11 \\
\hline 20-30 Years & 93 & 46.5 \\
\hline 30-40 Years & 48 & 24.0 \\
\hline 40-50 Years & 21 & 10.5 \\
\hline 50-60 Years & 16 & 8.0 \\
\hline Total & $\mathbf{2 0 0}$ & $\mathbf{1 0 0 . 0}$ \\
\hline \multicolumn{3}{|c|}{ Table 2: Age Distribution } \\
\hline
\end{tabular}

Fig. 5: Chancroid 


\begin{tabular}{|c|c|c|}
\hline $\begin{array}{c}\text { Educational } \\
\text { Status }\end{array}$ & $\begin{array}{c}\text { No. of } \\
\text { Patients }\end{array}$ & $\begin{array}{c}\text { Percentage } \\
\text { (\%) }\end{array}$ \\
\hline Uneducated & 74 & 37 \\
\hline Primary Edu., & 58 & 29 \\
\hline Secondry Edu., & 36 & 18 \\
\hline Higher Edu., & 32 & 16 \\
\hline Total & $\mathbf{2 0 0}$ & $\mathbf{1 0 0}$ \\
\hline \multicolumn{2}{|r}{ Table 3: Educational Status } \\
\hline
\end{tabular}

\begin{tabular}{|c|c|c|}
\hline M.C. Lesions & 13 & 6.5 \\
\hline Chancre & 07 & 3.5 \\
\hline Chancroid & 08 & 4.0 \\
\hline Donovanosis & 04 & 2.0 \\
\hline L.G.V & 02 & 1.0 \\
\hline Miscellaneous & 48 & 24.0 \\
\hline Total & $\mathbf{2 0 0}$ & 100.0 \\
\hline \multicolumn{2}{|c|}{ Table 5: Clinical Diagnosis } \\
\hline
\end{tabular}

\begin{tabular}{|c|c|c|}
\hline $\begin{array}{c}\text { Sexual } \\
\text { Exposures }\end{array}$ & $\begin{array}{c}\text { No. of } \\
\text { Patients }\end{array}$ & $\begin{array}{c}\text { Percentage } \\
(\%)\end{array}$ \\
\hline $\begin{array}{c}\text { No extra Marital/ } \\
\text { Premarital Exposures }\end{array}$ & 126 & 63 \\
\hline $\begin{array}{l}\text { Multiple Exposures } \\
\text { with single partner }\end{array}$ & 12 & 6 \\
\hline $\begin{array}{l}\text { Multiple Exposures with } \\
\text { Multiple partners }\end{array}$ & 26 & 13 \\
\hline Multiple Exposures & 36 & 18 \\
\hline Total & 200 & 100 \\
\hline \multicolumn{3}{|c|}{ Table 4: Sexual Exposures } \\
\hline
\end{tabular}

\begin{tabular}{|c|c|c|}
\hline $\begin{array}{l}\text { Cytology } \\
\text { Reports }\end{array}$ & $\begin{array}{c}\text { No. of } \\
\text { Patients }\end{array}$ & $\begin{array}{c}\text { Percentage } \\
(\%)\end{array}$ \\
\hline Normal Cytology & 78 & 39 \\
\hline Inflammatory Cytology & 52 & 26 \\
\hline Mild Dysplasia & 32 & 16 \\
\hline Moderate Dysplasia & 27 & 13.5 \\
\hline Severe Dysplasia & 11 & 5.5 \\
\hline Total & 200 & 100 \\
\hline \multicolumn{3}{|c|}{ Table 6: Cytology Reports } \\
\hline
\end{tabular}

\begin{tabular}{|c|c|c|}
\hline $\begin{array}{c}\text { Clinical } \\
\text { Diagnosis }\end{array}$ & $\begin{array}{c}\text { No. of } \\
\text { Patients }\end{array}$ & $\begin{array}{c}\text { Percentage } \\
\text { (\%) }\end{array}$ \\
\hline Genital Herpes & 36 & 18.0 \\
\hline Genital Warts & 17 & 8.5 \\
\hline Candidiasis & 38 & 19.0 \\
\hline Trichomoniasis & 27 & 13.5 \\
\hline
\end{tabular}

